\title{
PENGARUH INFLASI, EKSPOR DAN IMPOR TERHADAP PDB DI INDONESIA PERIODE 2015 - 2018
}

\author{
Putri Sari Margaret Juliyanti Silaban'1), Raysa Rejeki²) \\ 1) Fakultas Ekonomi, Program Studi Pendidikan Ekonomi Universitas Negeri Medan \\ E-mail: poetrisilaban@yahoo.com ${ }^{1}$, Raysarejeki2@ gmail.com ${ }^{2}$
}

\begin{abstract}
Abstrak
Penelitian ini bertujuan untuk menganalisis dan menjelaskan : (1) pengaruh simultan inflasi, ekspor dan impor terhadap PDB di Indonesia tahun 2018, (2) pengaruh parsial inflasi terhadap PDB di Indonesia tahun 2015-2018, (3) pengaruh parsial ekspor terhadap PDB di Indonesia tahun 2015-2018, (4) pengaruh parsial impor terhadap PDB di Indonesia tahun 2015-2018, penelitian ini menggunakan data sekunder berupa data time series, dimana penulis membatasi waktu penelitian dari tahun 2015-2018 data kuartalan, yaitu dengan data inflasi, ekspor, impor dan PDB. Metode analisis regresi berganda dengan menggunakan program Eviews 10. Hasil penelitian ini menunjukkan bahwa : (1) variabel inflasi, ekspor dan impor berpengaruh secara langsung dan simultan terhadap PDB, (2) variabel inflasi berpengaruh positif dan signifikan terhadap PDB, (3) variabel ekspor tidak berpengaruh signifikan terhadap PDB, (4) variabel impor tidak berpengaruh signifikan terhadap PDB.
\end{abstract}

Kata Kunci : Inflasi, Ekspor, Impor dan PDB, data Time Series 


\section{PENDAHULUAN}

Pertumbuhan ekonomi merupakan salah satu indikator yang sangat penting dalam mengukur keberhasilan pembangunan ekonomi yang terjadi pada suatu negara. Hal ini selaras dengan apa yang disampaikan Sukirno (2011:49), bahwa dengan mengamati tingkat pertumbuhan ekonomi yang tercapai dari tahun ke tahun dapatlah dinilai prestasi dan kesuksesan negara tersebut dalam mengendalikan kegiatan ekonominya dalam jangka pendek dan usaha mengembangkan perekonomiannya dalam jangka panjang.

Pertumbuhan ekonomi menjadi tolak ukur sejauh mana aktivitas perekonomian negara tersebut akan menghasilkan tambahan pendapatan bagi masyarakat pada suatu periode tertentu. (Todaro, 2005). Menurut Sukirno (2000) dalam analisis makro, tingkat pertumbuhan ekonomi yang dicapai oleh suatu negara diukur dari perkembangan pendapatan nasional riil yang dicapai suatu negara/daerah. Hal ini terjadi karena pada dasarnya kegiatan perekonomian merupakan suatu proses penggunaan faktor-faktor produksi untuk menghasilkan output, yang diukur dengan menggunakan indikator PDB.

PDB adalah salah satu faktor yang memberikan kontribusi sebagai faktor utama dalam mengukur kesehatan pereknomian suatu Negara. Menurut Mankiw (2007), dalam analisis makro pengukuran perekonomian suatu negara adalah Produk Domestik Bruto (PDB). PDB mengukur nilai barang dan jasa yang diproduksi di wilayah suatu negara tanpa membedakan. Pada suatu periode waktu tertentu.

PDB Indonesia menunjukkan pada tahun 2018 atas dasar harga konstan sebesar Rp10.425,3 triliun meningkat dibandingkan tahun 2015 yakni Rp8.982 triliun. Selama periode 2015-2018 Ekonomi Indonesia tumbuh rata-rata sebesar 5,04 persen.

\section{Gambar 1}

\section{Grafik Pertumbuhan PDB Triwulan} Tahun 2015-2018 (persen)



bahwa inflasi merupakan salah satu permasalahan utama dalam perekonomian. Salah satu akibat dari inflasi adalah perlambatan pertumbuhan ekonomi (Sukirno, 2011:15).

\section{NIAGAWAN Vol 9 No 1 Maret 2020}

Bank Indonesia menyatakan bahwa inflasi yang tidak stabil akan menciptakan ketidakpastian bagi pelaku ekonomi dalam mengambil keputusan, yang pada akhirnya akan menurunkan pertumbuhan ekonomi (www.bankindonesia.go.id, diakses pada 26 April 2017). Inflasi merupakan masalah yang banyak disoroti pemerintah Indonesia maupun negara lain. Sukirno (2011:333) menjelaskan bahwa tujuan jangka panjang pemerintah adalah menjaga agar tingkat inflasi yang berlaku berada di tingkat yang rendah

Gambar 2

\section{Grafik Laju Inflasi Indonesia Tahun 2015-} 2019



Sumber : BPS (Badan Pusat Statistika)

Adapun pertumbuhan inflasi di Indonesia periode 2015-2019 dapat kita lihat grafik diatas menunjukkan bahwa laju inflasi dalam lima tahun cukup terkendalikan di kisaran 3-4 persen. Berdasarkan data BPS, inflasi pada tahun 2019 sebesar 3,39 persen (Yoy) dibawah target APBN di 3,5 persen.

Tingkat inflasi yang tinggi dapat menyebabkan beberapa efek buruk sebelum terjadinya krisis, diantaranya investasi produktif akan berkurang, tingkat kegiatan ekonomi menurun, semakin banyak pengangguran tercipta, produk-produk negara tersebut tidak dapat bersaing di pasar internasional, ekspor menurun sedangkan impor meningkat, dan kedudukan neraca pembayaran akan memburuk (Sukirno, 2011:339). Inflasi jika tidak ditangani dengan benar maka akan berpengaruh pada kemampuan ekonomi negara tersebut yang kemudian akan mempengaruhi pertumbuhan perekonomian dan kesejahteraan masyarakatnya.

Mengukur perkembangan perekonomian suatu negara juga dapat dilihat dari output yang dihasilkan negara tersebut. Setelah seluruh permintaan dari dalam negeri telah dipenuhi, satu-satunya cara untuk memperoleh pasaran adalah dengan mengekspor ke luar negeri (Sukirno, 2011:361). Jumlah ekspor dan jumlah impor dapat memberikan gambaran mengenai kemampuan sebuah negara dalam memproduksi barang maupun jasa.

Kegiatan ekspor dan impor mempunyai peran penting bagi pertumbuhan ekonomi. Pada saat sebuah negara mempunyai keunggulan sebuah produk yang tidak bisa dihasilkan oleh negara lain dan negara tersebut membutuhkan 
produk, maka negara tersebut dapat mengekspornya. Net export akan mampu mendatangkan devisa bagi negara untuk menambah cadangan devisa dalam negeri yang nantinya akan digunakan sebagai pembayaran utang luar negeri yang jumlahnya sangat besar dan juga devisa yang didapat dari hasil ekspor akan dimanfaatkan untuk mengimpor bahan baku dan barang modal yang belum bisa dihasilkan di dalam negeri dan diharapkan mampu memajukan pertumbuhan industri dalam negeri (Saputra, 2016).

Gambar 3

Nilai Ekspor Indonesia Tahun 2014-2018 (juta US\$)

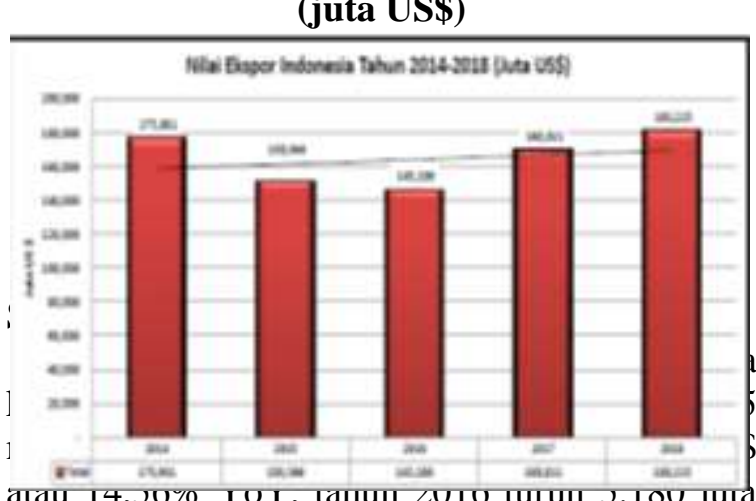

US\$ atau 3,44\% YoY. Nilai ekspor pada tahun 2017 naik sebesar US\$23.624njuta atau 16,27\% YoY. Tahun 2018 naik US\$ 11.404 juta atau $6,76 \%$ YoY. Rata-rata kenaikan nilai ekspor pada tahun 2017 s.d tahun 2018 adalah sebesar $12,06 \%$ per tahun.

Nilai Impor Indonesia Tahun 2014-2018 (juta US\$)

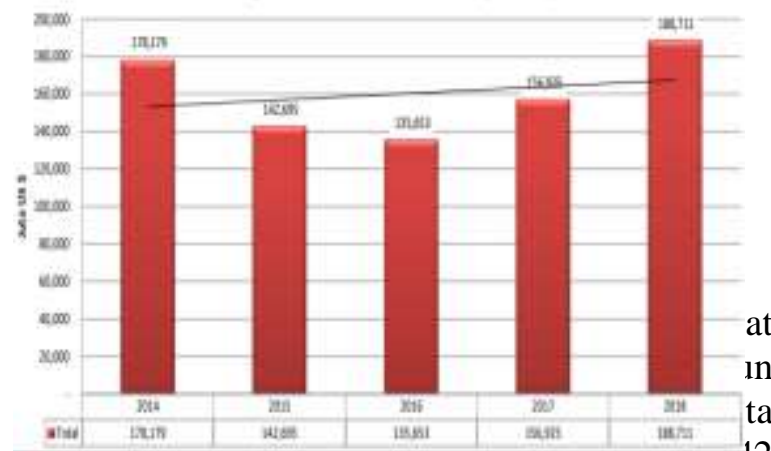

UND alau 19,9170 101 , talluil $\angle 010$ tuाuII 1.042 juta US\$ atau 4,93\% YoY. Nilai impor pada tahun 2017 naik sebesar US\$21.272 juta atau 15,68\% YoY. Tahun 2018 naik US\$ 31.786 juta atau 20,26\% YoY. Rata-rata penurunan nilai impor pada tahun 2014 s.d tahun 2016 adalah sebesar $11,93 \%$ per tahun.

\section{TINJAUAN PUSTAKA INFLASI}

Pada awalnya inflasi diartikan sebagai kenaikan jumlah uang beredar atau kenaikan likuiditas dalam suatu perekonomian. Pengertian tersebut mengacu pada gejala umum yang ditimbulkan oleh adanya kenaikan jumlah uang beredar yang diduga telah menyebabkan adanya kenaikan harga-harga.
NIAGAWAN Vol 9 No 1 Maret 2020

Dornbusch dan Fischer (2001), menyebutkan bahwa inflasi merupakan kejadian ekonomi yang sering terjadi meskipun kita tidak pernah menghendaki. Inflasi ada dimana saja dan selalu merupakan fenomena moneter yang mencerminkan adanya pertumbuhan moneter yang berlebihan dan tidak stabil.

Boediono (1980 : 105), mengemukakan bahwa defenisi inflasi adalah kecendrungan dari harga-harga untuk menaik secara umum dan terus menerus. Kenaikan harga dari satu atau dua barang saja tidak disebut inflasi, kecuali bila kenaikan tersebut meluas kepada (atau mengakibatkan kenaikan) sebagian besar dari harga-harga barang lain.

Dari defenisi tersebut ada tiga kriteria yang perlu diamati untuk melihat telah terjadinya inflasi, yaitu kenaikan harga, bersifat umum, dan terjadi terus menerus dalam rentang waktu tertentu. Apabila terjadi kenaikan harga satu barang yang tidak mempengaruhi harga barang lain, sehingga harga tidak naik secara umum, kejadian seperti itu bukanlah inflasi.

Adapun yang menjadi sumber Inflasi antara lain yaitu :

1. Inflasi karena permintaan (Demand Pull inflation)

2. Inflasi karena bertambahnya uang yang beredar

3. Inflasi karena kenaikan biaya produksi (Cost push inflation)

4. Inflasi campuran (Mixed inflation)

5. Inflasi ekspektasi (Expected inflation)

6. Kekacauan ekonomi dan politik Inflasi yang terjadi dapat dikelompokkan berdasarkan sifat, sebab terjadinya, dan berdasarkan asalnya.

a).Inflasi Berdasarkan Sifatnya

Berdasarkan sifatnya, inflasi dibagi menjadi empat kategori utama, yaitu

1) Inflasi Rendah (Creeping Inflation), yaitu inflasi yang besarnya kurang dari $10 \%$ per tahun.

2) Inflasi Menengah (Galloping Inflation), yaitu inflasi yang besarnya antara 10$30 \%$ per tahun.

3) Inflasi Berat (High Inflation), yaitu inflasi yang besarnya antara 30-100\% per tahun.

4) Inflasi Sangat Tinggi (Hyperinflation), yaitu inflasi yang ditandai oleh naiknya harga secara drastis hingga mencapai 4 digit (diatas 100\%).

b). Inflasi Berdasarkan Sebabnya

1) Demand Pull Inflation. Inflasi ini terjadi sebagai akibat pengaruh permintaan yang tidak diimbangi oleh peningkatan jumlah penawaran produksi.

2) Cost Push Inflation. Inflasi ini disebabkan kerena kenaikan biaya produksi yang disebabkan oleh kenaikan 
biaya input atau biaya faktor produksi. karena penurunan jumlah produksi.

3) Bottle Neck Inflation. Inflasi ini dipicu oleh faktor penawaran (supply) atau faktor permintaan (demand).

c). Inflasi Berdasarkan Asalnya

1) Inflasi yang berasal dari dalam negeri (domestic inflation).

2) Inflasi yang berasal dari luar negeri (imported inflation).

Adapun untuk menghitung inflasi dapat menggunakan pendekan sebagai berikut :

1. Indeks Harga Konsumen

IHK menggambarkan rata-rata perubahan harga antar periode waktu tertentu dari satu kelompok barang/jasa. Atas dasar penghitungan IHK maka akan diperoleh angka inflasi sebagai gambaran meningkatnya harga barang/jasa kebutuhan masyarakat yang dihitung berdasarkan bobot nilai konsumsi yang berlaku di suatu wilayah. IHK merupakan indikator penghitungan inflasi yang umum digunakan. Perhitungannya menggunakan rumus sebagai berikut :

$$
\begin{aligned}
& \text { Inflasi }=\frac{I H K_{n}-I H K_{n-1}}{I H K_{n-1}} \times 100 \% \\
& \text { IR }=\frac{I H K_{n}}{I H K_{n-1}} \times 100 \%-100 \%
\end{aligned}
$$

2. Indeks Harga Perdagangan Besar (IHPB)

IHPB adalah angka indeks yang menggambarkan besarnya perubahan harga pada tingkat grosir atau perdagangan besar dari komoditas-komoditas yang diperdagangkan disuatu daerah/negara. Perhitungannya menggunakan rumus sebagai berikut:

$$
\begin{aligned}
& \text { Inflasi }=\frac{I P H B_{n}-I P H B_{n-1}}{I P H B_{n-1}} \times 100 \% \\
& \text { IR }=\frac{I P H B_{n}}{I P H B_{n-1}} \times 100 \%-100 \%
\end{aligned}
$$

\section{Indeks Harga Implisit (GDP Deflator)}

Deflator PDB menggambarkan pengukuran level harga barang akhir dan jasa yang diproduksi di dalam suatu ekonomi. Untuk menghitung deflator PDB dapat dilakukan dengan cara membagi PDB nominal dangan PDB riil (berdasarkan harga konstan). Rumus yang digunakan adalah :

$$
\text { Deflator PDB }=\frac{P D B \text { Nominal }}{P D B \text { Rill }} \times 100 \%
$$

\section{EKSPOR}

Ekspor menurut keputusan menteri perdagangan dan perindustrian Nomor 182/MPP/KEP/4/1998 tentang ketentuan umum dibidang ekspor, menyatakan bahwa ekspor adalah kegiatan mengeluarkan barang dan jasa dari daerah kepabeanan suatu negara. Adapun daerah kepabeanan sendiri diartikan sebagai wilayah Republik Indonesia yang meliputi wilayah darat, perairan dan udara serta tempattempat tertentu di zona ekonomi ekslusif dan landas kontinen yang di dalamnya berlaku Undang-Undang No.10 tahun 1995 tentang Kepabeanan. Nilai ekspor adalah nilai transaksi barang ekspor sampai atas kapal pelabuhan muat dalam keadaan free on board (FOB). Jadi hasil yang diperoleh dari kegiatan ekspor adalah berupa nilai sejumlah uang dalam bentuk valuta asing atau yang biasa disebut dengan devisa, yang merupakan salah satu sumber pemasukan Negara. Sehingga ekspor adalah kegiatan perdagangan yang memberikan rangsangan guna menimbulkan permintaan dalam negeri yang menyebabkan timbulnya industri-indutri pabrik besar, bersamaan dengan struktur positif yang stabil dan lembaga sosial yang efisien.

Ekspor merupakan sumber devisa ditambah perluasan pasar bagi produksi barang domestik dan perluasan tenaga kerja. Perlu adanya perluasan ekspor yang dilakukan oleh suatu negara, karena komponen ekspor ini merupakan sumber devisa negara kita kurang lebih sebesar 70\%. Dalam teori Thomas Munn (tokoh ekonomi klasik) menyatakan perdagangan internasional akan menguntungkan neraca pembayaran suatu Negara asalkan mencapai kondisi $\mathrm{X}>\mathrm{M}$ (Ekspor lebih besar daripada Impor). Melalui asumsi inilah banyak negara tertarik untuk melakukan perdagangan internasional dengan melakukan pembukaan diri terhadapa internasional bahkan menargetkan peningkatan ekspor.

$$
\text { Menurut Sadono Sukirno }
$$
manfaat kegiatan ekspor :

1. Memperluas pasar bagi produk dalam negeri

2. Menambah devisa negara

3. Memperluas lapangan kerja

Ekspor suatu negara harus lebih besar daripada impor agar tidak terjadi defisit dalam neraca pembayaran.Oleh sebab itu pemerintah selalu berusaha mendorong ekspor melalui kebijakan ekspor dengan cara berikut :

1. Diversifikasi Ekspor/Menambah Keragaman Barang Ekspor

2. Subsidi ekspor

3. Premi ekspor

4. Devaluasi

5. Meningkatkan Promosi Dagang ke Luar Negeri

6. Menjaga Kestabilan Nilai Kurs Rupiah terhadap Mata Uang Asing

7. Mengadakan Perjanjian Kerja Sama Ekonomi Internasional

Dalam melaksanakan ekspor ke luar negeri dapat dilakukan dengan beberapa cara ,yaitu :

1. Ekspor Biasa

2. Barter

3. Konsinyasi (Consignment) 
4. Package-Deal

5. Penyelundupan (smuggling)

\section{IMPOR}

Impor adalah kegiatan memasukkan barang ke dalam daerah pabean (UURI No.17 Tahun 2006 Tentang Perubahan Atas UU No. 10 Tahun 1995 tentang Kepabeanan Pasal 1). Yang dimaksud dengan daerah pabean adalah wilayah Republik Indonesia yang meliputi wilayah darat, perairan dan ruang udara di atasnya, serta tempat-tempat tertentu di Zona Ekonomi Eksklusif dan landas kontinen yang di dalamnya berlaku Undang-Undang ini.

Menurut Susilo (2008:101) impor bisa diartikan sebagai kegiatan memasukkan barang dari suatu negara (luar negeri) ke dalam wilayah pabean negara lain (dalam negeri). Pengertian ini memiliki arti bahwa kegiatan impor berarti melibatkan dua negara. Dalam hal ini bisa diwakili oleh kepentingan dua perusahaaan antar dua negara tersebut, di mana satu pihak bertindak sebagai penjual (eksportir) dan satunya sebagai pembeli (importir).

Permendag No. 48/M-DAG/PER/7/2015

pasal 4 mengelompokkan barang

impor menjadi tiga golongan, yaitu :

1. Barang bebas Impor

2. Barang dibatasi Impor

3. Barang dilarang Impor

Sarpini (2011:3) menyebutkan 5 metode pembayaran dalam perdagangan

internasional, dalam hal ini impor, yaitu:

1. Pembayaran di Muka (Cash in Advance / Advance Payment)

2. Pembayaran Kemudian (Open Account)

3. Konsinyasi

4. Inkaso (Collection Basis)

5. Letter of Credit

\section{Produk Domestik Bruto (PDB)}

Produk Domestik Bruto (PDB) adalah jumlah nilai tambah barang dan jasa yang dihasilkan dari seluruh kegiatan perekonomian di seluruh negara dalam tahun tertentu atau periode tertentu dan biasanya satu tahun.

Metode perhitungan PDB ada dua macam, yaitu atas dasar harga berlaku dan atas dasar harga konstan. PDB atas dasar harga berlaku dapat dihitung melalui dua metode, yaitu:

\section{Metode Langsung}

Metode langsung dapat dilakukan dengan menggunakan tiga macam cara, yaitu pendekatan produksi, pendekatan pendapatan, dan pendekatan pengeluaran. Pendekatan Produksi adalah perhitungan nilai tambah barang dan jasa yang diproduksi oleh suatu kegiatan/sektor ekonomi dengan cara mengurangkan biaya antara dari total nilai total produksi bruto sektor atau sub
NIAGAWAN Vol 9 No 1 Maret 2020 sektor tersebut Dalam pendekatan pendapatan ini, nilai tambah dari kegiatan-kegiatan ekonomi dihitung dengan cara menjumlahkan semua balas jasa faktor produksi yaitu upah dan gaji, surplus usaha, penyusutan dan pajak tak langsung neto.

Sedangkan

pendekatan

pengeluaran adalah menjumlahkan nilai penggunaan akhir dari barang dan jasa yang diproduksi di dalam negeri.

$$
\text { Mankiw merumuskan }
$$

merumuskan perhitungan produk domestik bruto (PDB) sebagai berikut :

$$
\mathrm{Y}=\mathrm{C}+\mathrm{I}+\mathrm{G}+(\mathrm{X}-\mathrm{M})
$$

Sumber mankiw 2006 : 11

Keterangan :

$\mathrm{Y}=$ Pendapatan Domestik bruto (PDB)

$\mathrm{C}=$ konsumsi

$\mathrm{I}=$ Investasi

$\mathrm{G}=$ Pengeluaran Pemerintah

$\mathrm{X}-\mathrm{M}=$ Ekspor Netto

2. Metode Tidak Langsung adalah metode penghitungan dengan cara alokasi, yaitu mengalokir Produk Domestik Bruto Nasional menjadi PDB Provinsi dengan menggunakan beberapa indikator dan/atau indikator lainnya yang cocok sebagai alokator. Alokator yang digunakan dapat berupa: nilai produk bruto atau neto setiap sektor, jumlah produksi fisik, tenaga kerja, penduduk, dan alokator lainnya yang sesuai

$\mathrm{H}_{1}$ : Terdapat pengaruh parsial yang signifikan dari Inflasi (X1) terhadap PDB (Y) Indonesia Tahun 2015-2018

$\mathrm{H}_{2}$ : Terdapat pengaruh parsial yang signifikan dari Ekspor (X2) terhadap PDB (Y) Indonesia Tahun 2015-2018

$\mathrm{H}_{3}$ : Terdapat pengaruh parsial yang signifikan dari Impor (X3) terhadap PDB (Y) Indonesia Tahun 20152018

$\mathrm{H}_{4}$ : Terdapat pengaruh simultan yang signifikan dari Inflasi (X1), Ekspor (X2) dan Impor (X3) terhadap PDB (Y) Indonesia Tahun 20152018

\section{METODE PENELITITIAN}

\section{Jenis Penelitian}

Penelitian ini merupakan penelitian deskriptif kuantitatif untuk menjelaskan penngaruh inflasi, ekspor, impor terhadap PDB di Indonesia. 


\section{Jenis dan Sumber Data}

Penelitian ini dilakukan dengan cara data sekunder dalam bentuk angka yaitu inflasi, ekspor, impor dan PDB di Indonesia yang diambil dalam runtun waktu Tahun 2015-2018. Sumber-sumber data dalam penelitian ini diperoleh dari BPS yang kemudian diolah oleh peneliti dengan program Eviews 10.

\section{HASIL DAN PEMBAHASAN}

\section{Uji Asumsi Klasik}

\section{Uji Linieritas}

Tabel 1 Regresi Linearitas

Ramsey RESET Test

Equation: UNTITLED

Specification: PDB C IHK EKSPOR IMPOR

Omitted Variables: Squares of fitted values

\begin{tabular}{lccc}
\hline \hline & & & Probabilit \\
& Value & Df & y \\
\cline { 2 - 4 } & 0.73980 & & \\
t-statistic & 3 & 11 & 0.4749 \\
& 0.54730 & & \\
F-statistic & 9 & $(1,11)$ & 0.4749 \\
& 0.77691 & & \\
Likelihood ratio & 4 & 1 & 0.3781
\end{tabular}

Dari output diatas diperoleh nilai Probability F-statistic adalah 0,4749 lebih besar dari 0,05 maka dapat disimpulkan bahwa ada hubungan linear secara signifikan antara variable Inflasi (X1), Ekspor (X2) dan Impor (X3) dengan PDB sebagai variabel dependen (Y).

\section{Uji Normalitas}

\section{Gambar 6 Analisis Regresi uji Normalitas}



Berdasarkan output diatas diketahui bahwa nilai Prob Jarque-Bera sebesar 0,837908 lebih besar dari 0,05. Maka sesuai dengan dasar pengambilan keputusan dalam uji normalitas Jarque Bera, sehingga dapat disimpulkan bahwa data yang diuji berdistribusi normal.
NIAGAWAN Vol 9 No 1 Maret 2020

\section{Uji Multikolonieritas}

Tabel 2 Analisis Regresi uji Multikolonialitas

Variance Inflation Factors

Date: 11/30/19 Time: 11:43

Sample: 2015Q1 2018Q4

Included observations: 16

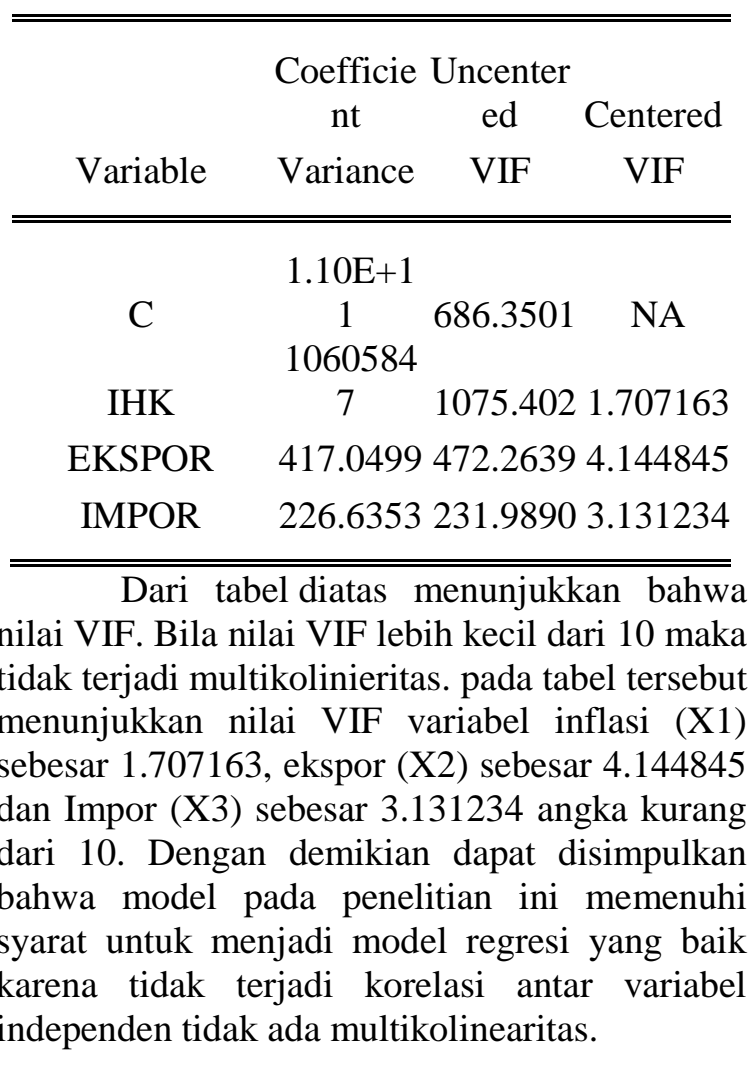

\section{Uji Autokorelasi}

\section{Tabel 3 Analisis Regresi uji Auto Korelasi}

Dependent Variable: PDB

Method: Least Squares

Date: 11/30/19 Time: 11:35

Sample: 2015Q1 2018Q4

Included observations: 16

\begin{tabular}{|c|c|c|c|}
\hline Variable & $\begin{array}{l}\text { Coeffici } \\
\text { ent }\end{array}$ & Std. Error t-Statistic & Prob. \\
\hline & & - & \\
\hline & 1115635 & 5 & \\
\hline $\mathrm{C}$ & 27801.6 & $6^{331707.53 .363309}$ & 0.0056 \\
\hline IHK & $\begin{array}{r}9 \\
5.98646\end{array}$ & $\begin{array}{l}93256.6628 .536868 \\
6\end{array}$ & 0.0000 \\
\hline EKSPOR & &  & 0.7744 \\
\hline & 6.62182 & 2 & \\
\hline IMPOR & & 915.054410 .439860 & 0.6679 \\
\hline
\end{tabular}

R-squared

0.91249 Mean dependent 242219

Adjusted R-

squared

S.E. of

regression



.






$5 \%$, jumlah sampel $n=16$ dan jumlah variabel $\overline{3}$ $(\mathrm{k}=3)=3.13$ maka diperoleh nilai du 1,7501 dan nilai dl 0,8140 sedangkan nilai DW 1,832372 lebih besar dari batas atau du yakni 1,7501 dan kurang dari (4-d) 4-1,7501 = 2,8499 maka sebagaimana dasar pengambilan keputusan dalam uji Durbin Watson, sehingga dapat disimpulkan bahwa tidak terdapat masalah atau gejala autokorelasi, maka analisis regresi linear berganda untuk uji hipotesis penelitian dapat dilakukan atau dilanjutkan.

\section{Uji Heteroskedastisitas \\ Tabel 4 Analisis Regresi uji} Heteroskedastisitas

Heteroskedasticity Test: Glejser

\begin{tabular}{|c|c|c|c|}
\hline F-statistic & 1.549512 & $\begin{array}{l}\text { Prob. F }(3,12) \\
\text { Prob. Chi- }\end{array}$ & 0.2527 \\
\hline uared & 4.467454 & quare(3) & 0.2152 \\
\hline xplained & & Prob. Chi- & \\
\hline 2 & 3.178240 & quare(3) & 0.36 \\
\hline
\end{tabular}

Berdasarkan Ouput diatas terlihat bahwa nilai Prob. Chi-Square adalah 0,2152 lebih besar dari 0,05 . Karena nilai signifikansi kedua variable lebih besar dari 0,05 maka sesuai dengan dasar pengambilan keputusan uji glejser, dapat disimpulkan bahwa tidak terjadi gejala heteroskedastisitas dalam model regresi.

\section{Analisis Regresi Berganda}

Tabel 5 Analisis Regresi Berganda

Dependent Variable: PDB

Method: Least Squares

Date: 11/30/19 Time: 11:35

Sample: 2015Q1 2018Q4

Included observations: 16

\begin{tabular}{crrrrr}
\hline \hline \multicolumn{5}{c}{$\begin{array}{c}\text { Coefficie } \\
\text { Variable }\end{array}$} & \multicolumn{4}{c}{ nt Std. Error } & t-Statistic & Prob. \\
\hline \hline C & \multicolumn{1}{c}{-} & & \\
IHK & 2715635. & 331707.5 & -3.363309 & 0.0056 \\
EKSPOR & 5.986466 & 20.42180 & 0.293141 & 0.7744 \\
IMPOR & 6.621829 & 15.05441 & -0.439860 & 0.6679 \\
\hline \hline
\end{tabular}

$\mathrm{PDB}=-1115634.72487+27801.6943856 *$ Inflasi $+5.98646586324 *$ EKSPOR $6.6218292131 *$ IMPOR.

\section{Uji Hipotesis}

\section{Uji Secara Parsial (Uji-T) \\ a. Inflasi}

Hasil analisis Uji $\mathrm{T}$ untuk variabel Inflasi diperoleh nilai T hitung sebesar 8.536868 $>1.77093$ dengan siginifikasi sebesar $0.0000<$ 0,05. Hal ini berarti $\mathrm{H}_{0}$ ditolak dan $\mathrm{H}_{\mathrm{a}}$ diterima. Sehingga dapat disimpulkan bahwa variabel Inflasi berpengaruh signifikan terhadap PDB tahun 2015-2018. Hasil penelitian ini sejalan dengan penelitian yang dilakukan oleh Irene Sarah Larasati dan Sri Sulasmiyati (2018) dengan judul "Pengaruh Inflasi, Ekspor dan Tenaga Kerja terhadap PDB Di Indonesia" dengan hasil penelitian ini menunjukkan bahwa inflasi berpengaruh yang signifikan terhadap PDB.

\section{b. Ekspor}

Hasil analisis Uji $\mathrm{T}$ untuk variable Ekspor diperoleh nilai $\mathrm{T}$ hitung sebesar $0.2943141<1.77093$ dengan siginifikasi sebesar $0.0007>0,05$. Hal ini berarti $\mathrm{H}_{0}$ diterima dan $\mathrm{H}_{\mathrm{a}}$ ditolak. Sehingga dapat disimpulkan bahwa variabel Ekspor tidak memiliki pengaruh terhadap PDB di Indonesia tahun 2015-2018. Hasil penelitian ini sejalan dengan hasil penelitian yang dilakukan oleh Suharjon, Sri Marwanti dan Heru Herointo dengan judul "Pengaruh Ekspor, Impor dan Investasi Terhadap Pertumbuhan Sektor Pertanian Indonesia" dengan hasil penelitian menunjukkan bahwa hasil analisis kausalitas menunjukkan bahwa ekspor, impor,dan investasi pertanian tidak berpengaruh nyata terhadap pertumbuhan PDB sektor pertanian.

\section{c. Impor}

Hasil analisis Uji $\mathrm{T}$ untuk variable Impor diperoleh nilai $\mathrm{T}$ hitung sebesar 0.439860 $<1.77093$ dengan siginifikasi sebesar 0.0007 > 0,05 . Hal ini berarti $\mathrm{H}_{0}$ diterima dan $\mathrm{H}_{\mathrm{a}}$ ditolak. Sehingga dapat disimpulkan bahwa variabel Impor tidak memiliki pengaruh terhadap PDB di 
Indonesia tahun 2015-2018.Hasil penelitian ini sejalan dengan hasil penelitian yang dilakukan oleh oleh Suharjon, Sri Marwanti dan Heru Herointo dengan judul "Pengaruh Ekspor, Impor dan Investasi Terhadap Pertumbuhan Sektor Pertanian Indonesia" dengan hasil penelitian menunjukkan bahwa hasil analisis kausalitas menunjukkan bahwa ekspor, impor,dan investasi pertanian tidak berpengaruh nyata terhadap pertumbuhan PDB sektor pertanian.

\section{Uji Secara Simultan (Uji-F)}

Berdasarkan table output diatas, diketahui nilai Prob (F-statistic) adalah sebesar 41.71153 Sedangkan untuk f table yakni sebesar 3,41. Karena nilai F-statistic 41.71153> 3,41, dengan nilai signifikansi $0.000001<0.05$ maka sesuai dengan dasar pengambilan keputusan dalam uji $\mathrm{F}$ dapat disimpulkan bahwa hipotesis diterima atau dengan kata lain Inflasi (X1), Ekspor (X2), dan Impor (X3) secara simultan berpengaruh terhadap PDB (Y). Hasil penelitian ini sejalan dengan hasil penelitian yang dilakukan oleh Tri Norma Verawati (2010) dengan judul " Pengaruh Inflasi, Ekspor dan Kurs terhadap Produk Domestik Bruto Indonesia Tahun 2000-2004" dengan hasil penelitian bahwa inflasi, ekspor dan kurs terdapat pengaruh yang signifikan terhadap PDB.

\section{Uji Koefisien Determinasi}

Nilai R-Square sebesar 0.890618 menunjukkan bahwa proporsi pengaruh variabel IHK, Ekspor, dan Impor terhadap PDB sebesar $89 \%$, sedangkan sisanya sebesar $11 \%$ dipengaruhi oleh variabel lain diluar dari variabel yang diteliti, misalnya kurs, tenaga kerja dan lainnya.

\section{KESIMPULAN DAN SARAN}

\section{Kesimpulan}

Berdasarkan uji f diketahui Prob (F-statistic) adalah sebesar 41.71153 Sedangkan untuk f table yakni sebesar 3,41. Karena nilai F-statistic $41.71153>3,41$, dengan nilai signifikansi $0.000001<0.05$ maka sesuai dengan dasar pengambilan keputusan dalam uji $\mathrm{F}$ dapat disimpulkan bahwa hipotesis diterima atau dengan kata lain inflasi (X1), Ekspor (X2) dan Impor (X3) secara simultan berpengaruh terhadap PDB (Y).

Berdasarkan uji t inflasi (X1) berpengaruh positif dan signifikan terhadap PDB (Y) sebesar nilai $\mathrm{T}$ hitung sebesar $8.536868>1.77093$ dengan siginifikasi sebesar $0.0000<0,05$.

Berdasarkan uji $t$ Ekspor (X2) tidak berpengaruh terhadap PDB (Y) dengan nilai T hitung sebesar $0.2943141<1.77093$ dengan siginifikasi sebesar $0.0007>0,05$,
NIAGAWAN Vol 9 No 1 Maret 2020

Berdasarkan uji t Impor (X3) berpengaruh tidak berpengaruh terhadap PDB (Y) dengan nilai $\mathrm{T}$ hitung sebesar $0.439860<1.77093$ dengan siginifikasi sebesar $0.0007>0,05$.

\section{Saran}

\section{Bagi Pemerintah}

Bagi Pemerintah Indonesia supaya lebih memperhatikan permasalahan dan tepat dalam mengambil kebijakan yaitu pemerintah harus menurunkan tingkat inflasi dan meningkatkan ekspor dan mengurangi impor sehingga dapat meningkatkan PDB di Indonesia.

\section{Bagi Peneliti Selanjutnya}

Kepada peneliti selanjutnya,agar kiranya karya ilmiah ini dapat dijadikan referensi atau rujukan di masa yang akan datang. Penulis menyarankan kepada peneliti hendaknya menambahkan atau menggunkan variabel-variabel bebas yang lain agar dapat menambah wawasan dan pengetahuan.

\section{Bagi Pembaca}

Diharapkan dengan adanya makalah penelitian ini dapat membantu pembaca dalam memahami pengaruh Inflasi, Ekspor, Impor terhadap PDB Periode 2015 - 2018, serta dapat berguna dalam mempelajari ekonomi Indonesia

\section{REFERENSI}

Amir M.S. (2003). Seluk Beluk dan Teknik Perdagangan Luar Negeri Seri Umum No.2. Jakarta : PT. Pustaka Binaman Pressindo.

Astuti, Ismadiyanti Purwaning dan Fitri Juniwati Ayuningtyas. 2018. Pengaruh Ekspor dan Impor Terhadap Pertumbuhan Ekonomi di Indonesia. Jurnal Ekonomi dan Studi Pembangunan. 19 :1 : 1-10.

Boediono. 2001. Ekonomi Internasional. BPFE UGM : Yogyakarta.

Dornbusch, Rudiger dan Fischer, Stanley. 1997. Makro Ekonomi. Erlangga : Jakarta.

Larasati, Irene Sarah Dan Sri Sulasmiyati. 2018. Pengaruh Inflasi, Ekspor, Dan Tenaga Kerja Terhadap Produk

Domestik Bruto (PDB) (Studi Pada Indonesia, Malaysia, Singapura, Dan

Thailand). Jurnal Administrasi Bisnis (JAB). $63: 1:$ 8-16.

Lia Amaliawiati dan Asfia Murni. 2014. Ekonomika Mikro. Bandung: PT Refika Aditama.

Mankiw, N. Gregory. 2006. Pengantar Ekonomi Makro. Jakarta : Salemba Empat. 
Muhamad Abdul Halim. 2012. Teori

Ekonomika, Edisi 1. Jakarta : Jelajah Nusa.

Nanga, Muana. 2005. Makroekonomi : Teori,

Masalah dan Kebijakan. Edisi Kedua.

Jakarta: PT. Raja Grafika Persada.

Pranoto, Oscar Surya. 2016. Pengaruh Ekspor

Dan Foreign Direct Investment

Terhadap Pertum buhan Domestik

Bruto Indonesia. Jurnal JIBEKA. $10: 1$ : 49-53.

Samuelson, Paul A \& Nordhaus, WD, 2005. Ilmu Makroekonomi, Edisi ke - 17, Jakarta : Salemba Empat.

Soediyono Reksoprayitno. 1992. Ekonomi Makro (Analisa IS-LM dan Permintaan-Penawaran Agregatif). Yogyakarta: Liberty.

Suherman Rosyidi. 2011. Pengantar Teori Ekonomi. Jakarta : PT Rajagrafindo Persada.

Sukirno, Sadono. 2016. Makro Ekonomi :

Teori Pengantar. Jakarta : Rajawali Pers.

Suharjon, Sri Marwanti dan Heru Herointo. "Pengaruh Ekspor, Impor dan Investasi Terhadap Pertumbuhan Sektor Pertanian Indonesia". 2017. Jurnal Agro Ekonomi 2017: 49-65.

Tati Suhartati Joesron dan M. Fathorrazi. 2012. Teori Ekonomi Mikro. Yogyakarta: Graha Ilmu.

Tri Norma Verawati “ Pengaruh Inflasi, Ekspor dan Kurs terhadap Produk Domestik Bruto Indonesia Tahun 2000-2004". 2010.

https://www.researchgate.net/publicati on/50951712_PENGARUH_INFLASI _EKSPOR_DAN_KURS_TERHADA P_PRODUK_DOMESTIK_BRUTO_I NDONESIA_TAHUN_2000-2004

Yudistira, I Made dan I Gede Sujana Budhiasa. 2013. Analisis Pengaruh Konsumsi, Investasi, dan Inflasi Terhadap Produk Domestik Bruto di Indonesia Tahun 2000-2012.

E-Jurnal Ekonomi Pembangunan Universitas Udayana. $2: 11$ : 492- 501. 